\title{
Evaluation of Roof Bolting Requirements Based on In-Mine Roof Bolter Drilling
}

(Contract No. DE-FC26-01NT41056)

Project Duration: Dec. 18, 2000 - Dec. 17, 2003

\section{Quarterly Technical Progress Report}

\author{
Report Period \\ July 1, 2001 - September 30, 2001
}

Syd S. Peng (Principal Investigator)

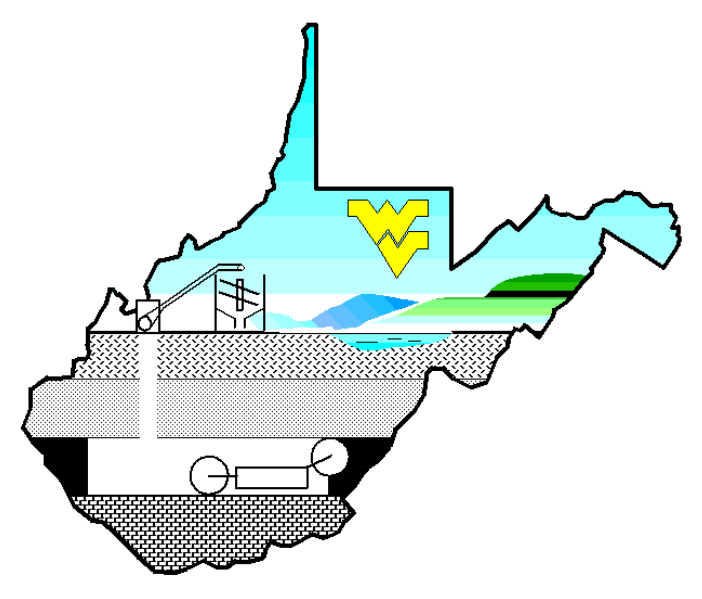

Department of Mining Engineering

West Virginia University

Morgantown, WV 26506-6070

Tel: 304-293-7680 ext. 3301

E-mail:sspeng@mail.wvu.edu

October 15, 2001 


\title{
DISCLAIMER
}

This report was prepared as an account of work sponsored by an agency of the United States Government. Neither the United States Government nor any agency thereof, nor any of their employees, makes any warranty, express or implied, or assumes any legal liability or responsibility for the accuracy, completeness, or usefulness of any information, apparatus, product, or process disclosed, or represents that its use would not infringe privately owned rights. Reference herein to any specific commercial product, process, or service by trade name, trademark, manufacturer, or otherwise does not necessarily constitute or imply its endorsement, recommendation, or favoring by the United States Government or any agency thereof. The views and opinions of authors expressed herein do not necessarily state or reflect those of the United States Government or any agency thereof.

\begin{abstract}
The retrofitting works for a dedicated roof bolter for this research has been completed. The laboratory tests performed using this machine on simulated roof blocks have been conducted. The analysis performed on the testing data showed promising signs to detect the rock interface, fractures, as well as the rock types. The other tasks were progressing as planned.
\end{abstract}




\section{TABLE OF CONTENTS}

Disclaimer
Abstract
Research Objectives
Experimental
Results and Discussion
1. Roof Mapping - data processing and preliminary results
2. Exploring the Roof Bolting Mechanisms
3. Development of On-Board Data Visualization and Database Program
Scheduled presentation
Conclusions 


\section{$\underline{\text { Research Objectives }}$}

Roof bolting is the most popular method for underground openings in the mining industry, especially in the bedded deposits such as coal, potash, salt etc. In fact, all U.S. underground coal mine entries are roof-bolted as required by law.

However, roof falls still occur frequently in the roof bolted entries. The two possible reasons are: the lack of knowledge of and technology to detect the roof geological conditions in advance of mining, and lack of roof bolting design criteria for modern roof bolting systems.

This research is to develop a method for predicting the roof geology and stability condition in real time during roof bolting operation. Based on such information, roof bolting design criteria for modern roof bolting systems will be developed for implementation in real time.

For the prediction of roof geology and stability condition in real time, a microprocessor will be used and a program (ROOFSTAB) developed to monitor the drilling parameters. These parameters include thrust, penetration rate, rotation torque, rotation rate, drill position, and vacuum condition. At the same time, rock cores will be obtained a borehole drilled immediate next to bolt hole for the determination of the mechanical properties and structure of the rock strata within the bolting horizon. A relationship or relationships will be established between these drilling parameters and the mechanical and structural data of the roof strata. A roof bolter control system will be developed to monitor these drill parameters. For the development of ROOFSTAB drilling parameters will be obtained from four different coal seams in four mine sites. With this information, a computer program will be developed for use in conjunction with the roof bolter for realtime prediction of strata mechanical properties and structures in roof strata within the bolting horizon.

For the development of roof bolting design criteria, numerical simulations will be performed to investigate the mechanisms of modern roof bolting systems including both the tension and non-tensioned (or fully grouted) bolts. Parameters to be studied are: bolt size/strength, bolt length, bolt spacing, grout annulus and length, and roof geology (massive strata, fractured, and laminated or thinly-bedded). The results of these experiments will be analyzed to develop a roof bolting criterion or criteria program (ROOFBOLT) that will be combined with the ROOFSTAB for use in conjunction with roof bolt installation.

The following main tasks are to be performed for achieving the proposed research objectives:

A. Development of Operator Control Technology for Monitoring Roof Bolter Drill Operations Parameters.

B. Laboratory and Underground Testing.

C. Drill Parameters Data Analysis and Correlation with Roof Stability Conditions Software Development for Mapping of Roof Geological Conditions

D. Laboratory Tests to Investigate the Mechanisms of Roof Bolting Using Simulated Materials

E. Development of Roof Bolting Design Criteria for Implementation in Primary Roof Bolting Cycle 


\section{EXPERIMENTAL}

The construction of the dedicated roof bolter has been completed (Fig. 1). This is a dual head arm feed roof bolter. The new feedback control system redesigned based on the preliminary experiments has also been completed. Laboratory experiments were performed using the dedicated roof bolter at J. H. Fletcher plant in Huntington, WV during this reporting period. Two sets of experiments using the newly completed dedicated roof bolter were performed on two artificially made concrete blocks: 21 holes on the solid block and 8 holes on the fractured block. More tests are planned in the next quarter to further confirm those conclusions before undertaking the underground mine tests.

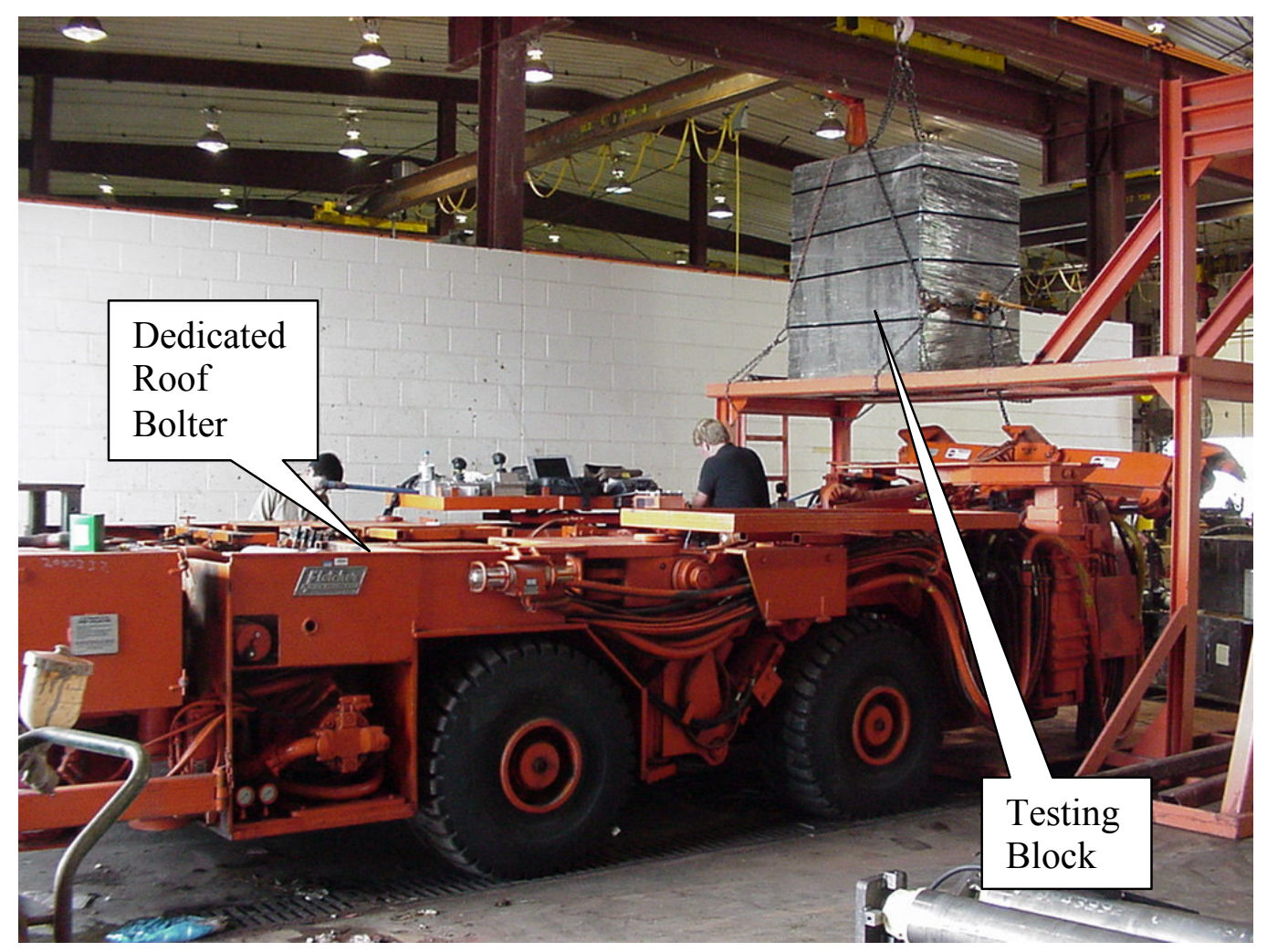

Fig. 1 Laboratory Experiments at Fletcher's Huntington Facility

\section{RESULTS AND DISCUSSION}

The objective of this research project is to develop the methodology for evaluating the geology and stability condition of the roof strata of underground openings in realtime during roof bolting operation. Based on such information, bolting requirements for 
modern roof bolting systems will be developed for implementation in real time. The results of the works performed in this reporting period are briefly discussed:

\section{Roof Mapping - data processing and preliminary results}

Preliminary results of these two sets of laboratory tests using the newly retrofitted roof bolter dedicated for this research are very encouraging. It showed:

a. For identification of voids and fractures, thrust and torque can both be used for determining the location of voids and fractures. Because both thrust and torque drop down sharply when encountering voids or fractures. However the determination of size (or width) of voids and fractures needs further analysis.

b. For identification of interface between two adjacent layers, the rotational acceleration of the drill rotational speed can be used. Re-visit of the experimental data on rock layer blocks tested prior to contract award showed that $75 \%$ of the time the drill rotation speed either accelerates or decelerates within 2-4 in of the interface, depending on the rock types that the drill is drilling away or into softer or stronger rock.

c. For identification of rock type, a bit mechanics model using the bit geometry and the maximum free cutting depth and cutting area of the tungsten carbide has been developed. It was found the curves of thrust/torque vs. penetration per revolution are linear which can be used to predict rock strength.

\section{Exploring the Roof Bolting Mechanisms}

d. The development of two-dimensional FE (finite element) model for fully grouted resin bolting has been completed. The model has been validated with a case study of roof-bolt load monitoring data for a two-entry system longwall gateroad. A pa-per is being prepared for publication.

e. Since bedding planes play a very important role in roof bolting design, the strength of various bedding planes for rock cores from two boreholes in two mines were tested in the laboratory. The bedding planes between four rock types were determined. The bedding planes are not smooth in most cases and their strength is much weaker than the rock itself.

\section{Development of On-Board Data Visualization and Database Program}


Analysis of the software requirements for this project showed that there is no commercial software available and that special software will have to be developed. The proposed tools are:

* Database: Microsoft Access

* Visualization: OpenGL, VC++

* User Interface: VB, VC++

Database design in combination with user interface design is under way. Programming for displaying 3D color images has been completed.

\section{Progress on Planned Tasks}

\begin{tabular}{rl|l}
\hline \hline \multicolumn{1}{c|}{ Tasks Planned in the Proposal } & \multicolumn{1}{c}{ Progress } \\
\hline A. $\quad \begin{array}{l}\text { Development of Operator Control Technology for Monitoring Roof } \\
\text { Bolter Drill Operation Parameters }\end{array}$ & $\begin{array}{l}\text { As detailed in item No. 1. } \\
\text { Approximately 4-month } \\
\text { delay }\end{array}$ \\
\hline B. $\quad$ Laboratory and Underground Testing & $\begin{array}{l}\text { As detailed in item 1. } \\
\text { Laboratory experiments } \\
\text { had begun. }\end{array}$ \\
\hline C. $\quad \begin{array}{l}\text { Drill Parameter Data Analysis and Correlation with Roof Stability } \\
\text { Conditions }\end{array}$ & As detailed in item No. 2 \\
\hline D. $\quad \begin{array}{l}\text { Software Development for Mapping of Roof Geological Condi- } \\
\text { tions }\end{array}$ & $\begin{array}{l}\text { As detailed in item No. 4. } \\
\text { On schedule }\end{array}$ \\
\hline E. $\quad \begin{array}{l}\text { Computer Modeling to Investigate the Mechanisms of Roof Bolt- } \\
\text { ing }\end{array}$ & $\begin{array}{l}\text { As detailed in item No. 3. } \\
\text { On schedule.. }\end{array}$ \\
\hline F. $\begin{array}{l}\text { Development of Roof Bolting Design Requirements for Implemen- } \\
\text { tation in the Primary Roof Bolting Cycle }\end{array}$ & None \\
\hline \hline
\end{tabular}

\section{SCHEDULED PRESENTATION}

S.S. Peng, "Roof Mapping by Roof Bolter Drilling Parameters - progress report." Paper to be presented at the West Virginia Coal Mining Institute/Society of Mining Engi-neer, Inc/Central Appalachian Section Joint Fall Meeting, the Greenbrier, White Sculpture Spring, WV, and October 18-20, 2001.

\section{CONCLUSIONS}

The retrofitting works for a dedicated roof bolter for this research has been completed. The laboratory tests performed using this machine on simulated roof blocks have been conducted. The analysis performed on the testing data showed promising signs to detect the rock interface, fractures, as well as the rock types. The other tasks were progressing as planned. 